\title{
Quest for the Female Self-awareness in Iris Murdoch's A Fairly Honourable Defeat
}

\author{
Mingying Xu \\ Dalian University of Technology, Dalian, China
}

\begin{abstract}
This paper is devoted to examine the reconstruction of female selfhood from the aspect of the growth of female self-consciousness in a changed and revised world through the quest for female self-awareness as an individual in Iris Murdoch's A Fairly Honourable Defeat. Through the analysis of Iris Murdoch's comparative characterization of the siblings Hilda and Morgan, the paper reveals that the social and economic changes in the modern world and all kinds of women's liberation movements will necessarily lead to the improved situation of women if they have no capacity for introspection and the ability to reconcile themselves as an individual separate from the environment and other individuals. Compared with Morgan's emotional perplexity, economic hardship, and male contempt, Hilda's affluent life, happy marriage and her popularity among the male indicate Murdoch's reluctant admission that women still live in the androcentric world where the women's self-improvement are not widely welcome.
\end{abstract}

Index Terms-Iris Murdoch, female self-awareness, quest

\section{INTRODUCTION}

The developments that occurred in British society during the 1960s and 1970s must be taken into consideration in order to explore Murdoch's characterization of the female characters in her novels. Martin Pugh notes that the Women's Liberation Movement expedited progress in Great Britain though women were still struggling for equality in some respects during the late 1960s and early 1970s. He points out that the advances for women are embodied in more employment opportunities for woman. Besides, Pugh also notes that people began to change the attitudes toward marriage and didn't consider it as a social ideal (Pugh, 2000, p.314-5). Under these circumstances, Murdoch's depiction of the female characters in this period reflects these social changes accordingly as these women's views on marriage and career are consistent with opportunities increasingly available to women in the 1970s.

Along with these social developments, Murdoch explores the themes of good and evil, form and contingency and the growth of women's self-consciousness in the novel A Fairly Honourable Defeat published in 1970 after twelve previous novels. The central character in this novel is Julius King, a Jewish American biochemist in his mid-forties, who throws the lives of several friends into disarray by the machinations for his bet with his ex-girlfriend Morgan Browne that he can take advantage of human weaknesses and break up any relationship only if he wants. Using a mixture of high cunning schemes and garbled letters, Julius puts his friends in situations which they would never have anticipated and which ultimately result not only in the revelation of their character flaws but also in the death of Rupert, for which Julius takes no responsibility. From these happenings, everyone realizes their ridiculous vulnerability: Axel and Simon strengthen their love and become less shamefaced about being homosexual; Morgan Browne and her elder sister Hilda Rupert increase the female self-consciousness in the marriage and love dilemma.

In this novel, the female character Morgan is so empowered that she has much more power, education and independence than many of the female characters in Murdoch's other novels. And another female character Hilda is also a shining example of middle-class women with a beautiful and satisfactory matrimonial connection. However, at the beginning of the narrative, their seemingly honourable life fails to endow them with female self-consciousness and then save them from Julius's trap. In Murdoch's view, Julius's success as puppeteer is highly due to his victims' lack of an adequate theory of personality. In her earlier essays, Murdoch has "challenged existentialism's as well as British empiricism's stress on sincerity" (Dipple, 1982, p.191), and contended that "in the contemporary world accurate and humble knowledge of the self has been obscured by these grand theories. The result is the inability of contemporary people to think outside themselves or to effect desired real change or amelioration" (Dipple, 1982, p. 191). As the plot processes, Morgan and her sister gradually enhance their self-consciousness through their attempts to quest for the female self-awareness and liberate from androcentric fantasy while encountering with the plights of love and marriage relationships.

Self-awareness is defined as the capacity for introspection and the ability to reconcile oneself as an individual separate from the environment and other individuals. As the conscious understanding of one's thoughts, feelings, actions and interpersonal connections, self-awareness can help him/her gain insight into the factors that influence the external world as well as the internal beliefs, values and morals. In The Second Sex, Beauvoir states that "One is not born, but rather becomes a woman" (Butler, 1986, p. 35). Gender is shaped by social, cultural, and historical forces. Her assertion is that social forces work together to construct femininity and make women depend upon men. According to 
Beauvoir, women become disempowered in their attempt to conform to the sociocultural expectation of female passivity. Women's dependence on and oppression by man hinder women from the acquisition of female self-awareness "because she is alienated in him - that is, her interests as an individual lie in him" (Beauvoir 465). In this novel, Murdoch portrays the ongoing process of Morgan and Hilda's quest for the female self-awareness by means of depicting the changes of their characters.

\section{Morgan: The ANGEL That LiVES ON EARTH}

As Tallis' malevolent wife and Hilda's younger sister, Morgan is a scholar in a theoretically based academic field with the intention to publish a book on her own linguistic theory. At the beginning of the narrative, she just returned to England after two-year teaching in America where she had an affair with Julius King to gain freedom for the constraints of "old-fashioned and exclusive" (Murdoch, 2001, p.194) marriage, which she describes to her husband Tallis as: "I've had a wonderful adventurous time these last two years. I've really lived. I'm not going into any more cages. We ought never to have got married" (Murdoch, 2001, p.111).

Murdoch has her personal preference for the female character Morgan Browne for she empowers this woman with a good education background, her own career and a seemingly independent life which Murdoch's previous female characters seldom own. Concerning the phenomenon that women are occupied by the unproductive housework in the marital home, Beauvoir maintains that having a career is essential for women's independence (Beauvoir, 1953, p.419). On this point, Murdoch believes that education is the essential way for women to change their female inferiority and their self-perception. When being asked in her interview with Sheila Hale about women's education, Murdoch responds:

"The problem for women is the way they think about themselves. Education is fundamental to their socially conditioned behaviour of inferiority. The wretched girls are demoralised at each age by fobbing off with soft subjects; and unless there is a positive move for women's education, there is no hope. But is education important for a writer? I'm told that it's not." (Dooley, 2003, p. 31)

Murdoch attaches great importance to women's education for the awakening of their female self-awareness while Beauvoir values the importance of women's career for their independence.

However, to their disappointment, all these factors fail to guarantee Morgan to possess a sound female self-awareness at the very beginning although she has strong sense of obtaining her self-consciousness. Morgan's first appearance in the novel leaves the reader an impression that she is greatly involved in a sentimental crisis, vacuous and depressed. After the breakup of a two-year extramarital affair with Julius, Morgan gave up her work, abandoned her students and went back to England from America. Her arrival at her sister Hilda's house, where there is a party for the Ruperts' $20^{\text {th }}$ anniversary, makes the people there surprised and then receives a warm welcome from them. But she reacts to their excitement rather indifferently with a blank stare across the pool. When Hilda embraces her warmly, "Morgan remained completely stiff, then jerked her head away. With a firm pressure of the hand she terminated Hilda's embrace" (Murdoch, 2001, p.39). Then "she looked round at them all with vague eyes, ... still standing rather stiffly and frowning against the sun" (39). She confesses to Hilda: "I don't know who I am, Hilda. I have no home" (Murdoch, 2001, p.43). And "I've lost all sense of time" (Murdoch, 2001, p.51). Morgan also claims to her brother-in-law Rupert that her mind is "bedlam" (Murdoch, 2001, p.78) and her heart is "dead" (Murdoch, 2001, p.78), although he tries to convince her saying "If you use your mind and your heart you can put everything together again" (Murdoch, 2001, p.78). When Hilda consults her about her future plan, Morgan replies:

'I don't know what I'm doing,' said Morgan. 'I don't know where I'm going. I have no plans. I have no intentions. I have no thoughts. I have just got off a jet plane and I feel crazy.' (Murdoch, 2001, p.40)

Although Morgan "feels mad and a wreck" (Murdoch, 2001, p.42), she starts to rethink her life with a little self-reflection and self-awareness rather than indulge in her depression. While looking at herself in the mirror, Morgan feels like to "say something to herself, something apt, something bracing and encouraging, something witty perhaps". Although "she could not formulate it and she looked at herself in silence, ... that moment of self-regard had strengthened her, as she knew it would." (Murdoch, 2001, p.42) Therefore, at the moment when Morgan can't see anything, herself and her marriage, she expects Hilda to "exist quietly near [her] while [she] discover who [she is] and what the purpose of life is" (Murdoch, 2001, p.45). Morgan then tells Hilda that she has got a "job", that is "to find out who I am and what life means. And to stop worrying about Tallis ... to set myself free..." (Murdoch, 2001, p.48). Hilda's care and support provide Morgan with a sense of safety and comfort her frail mind on some level, so that she is "only just beginning to feel human again"(Murdoch, 2001, p.77).

However, considering that becoming a woman with full self-awareness is imperative to resume her normal life and order, Morgan takes an unwise and wrong approach to attain it. She proves her existence by the manipulation of men's love and the establishment of personal relationship with them. Julius' comment on her is that "I am afraid you attach too much importance to personal relationships" (Murdoch, 2001, p.213). She implores the cruel love of her lover Julius at all costs, despises the faithful love of her husband Tallis, and even induces the ignorant love of her nephew Peter. Her physical attraction to Peter makes him attempt to make love with her, which causes her believe that she "can make him do anything [she] want[s] these days" (Murdoch, 2001, p.179). Regardless of Tallis' warning not to "mess around with Peter unless you're really prepared to commit yourself to him in some serious and sensible sort of way" (Murdoch, 
2001, p.194), Morgan argues: "Why shouldn't I be serious and sensible? I'm going to love people. That's what I mean by living differently. That'll be my new way of life. I'm going to be free and love people" (Murdoch, 2001, p.194). And she believes that she seems to "have succeeded where you all failed" (Murdoch, 2001, p.194). Julius' aloofness, Tallis' persistence and Peter's blind passion all make Morgan fulfilled and satisfied:

'Of course there's still so much - But I feel better. I can cope. Perhaps something divine has happened to me. I've made a discovery. [...] It is possible to love people. [...] Falling in love is something different, it's a form of madness. I think I just didn't realize that at this moment in time I was really capable of noticing other people at all or that I could come to care for people in a new way, in an unselfish unfrantic sort of way. I feel I've won a victory and I'm rather pleased with myself. There are good surprises after all. (Murdoch, 2001, p.179)

Indulged in the blind self-confidence and unreliable self-awareness, Morgan gets an unreal understanding of herself and these interpersonal relationships around her. Julius pinpoints her fatal weakness that her trouble is that she doesn't know who she is. So "the metaphysical search is always a sign of neurosis" (Murdoch, 2001, p.236).

Her conceitedness leads her to be trapped by Julius' machinations and then become his accomplice as well as a victim at the same time. She believes the lie made up by Julius about Rupert and decides to "come close to Rupert, help him to bear his private grief, keep the secret of the wildness within and transform by patience the violence of his love" (Murdoch, 2001, p.248) despite the possible offence to her sister. Moreover, "after so much misery and so many disappointments and so many people letting [her] down", Morgan still anchors her hope in her brother-in-law Rupert but not herself believing that he is "the one person who could really help" her if only he would "keep his head" (Murdoch, 2001, p.299) and everything "could be perfectly all right” (Murdoch, 2001, p.299).

After her affair with Rupert was uncovered, Morgan becomes upset by Hilda's departure and disillusioned by Rupert's responses to what happened. She considers Rupert as a "blind instrument of destruction" (Murdoch, 2001, p.387) in her reflection:

And Morgan blamed herself for not having rejected this dangerous frivolity at the very beginning. ...The sight of Rupert now would make her sick with shame and about the future of her relations with him she forbore to think. She reproached herself constantly with Hilda's voice, falling down in abject and passionate supplication before that accusing shade. (Murdoch, 2001, p.387)

The reflection on her misdoings brings the gradual establishment of her self-awareness back to the right track and makes her realize what she can't do and the shame of her previous misdemeanor causes her "groan with remorse" (Murdoch, 2001, p.387). Meanwhile, Morgan realizes that she focuses too much on herself and neglects her sister's personal life without asking her even "one searching question" (Murdoch, 2001, p.389), which embodies her increasing female self-awareness in another aspect.

Murdoch's characterization of Morgan exposes to the reader the new predicament of the woman who has better education and job opportunities than her female predecessors. Morgan's frustrated emotional experiences reveal the limited role of education and career in the establishment of the female self-awareness if the social ideology is still male-centered. And the reader really doubt what kind of independence and happiness women finally get through all these Women's Movements when they find Morgan, who makes herself agreeable nowhere, even suffers more emotional and financial troubles as well as personality flaws in the novel despite all the advantages she has:

Her cynicism about the abortion until Julius points out that there may be a moral issue and that the child might have salvaged the relationship, her great love towards Hilda which she lessens by claiming it cannot survive a financial or emotional transaction with Rupert, her lying to Tallis about money, her arrogant lying power over Peter, all contribute to the sense that she is demonic in her suffering. (Dipple, 1982, p.195)

Abandoning the conventional female virtues as "the Angel in the House", Morgan fails to acquire the new goodness as an independent woman. Instead her character weaknesses are becoming abusive to the people around her in her quest for her self-awareness. After Rupert's death, Morgan moves to America with her sister and resumes her teaching career, living a big house they bought. Morgan's depiction is a firm denial of the idea that the social and economic changes in the modern world and all kinds of women's liberation movements will necessarily lead to the improved situation of women if they have no capacity for introspection and the ability to reconcile themselves as an individual separate from the environment and other individuals. However, we cannot deny the fact that better education and more job opportunities enable Morgan, in her quest for the female self-awareness, to have more freedom to choose and have the possibility of a freshly new start, which is unimaginable and unreachable for her female predecessors.

\section{HiLdA: The ANGEL IN THE HouSE}

Murdoch's characterization of Hilda Foster, Morgan's elder sister, is directed towards the self-awareness of traditional females in the contemporary society. As a comparable character to Morgan, Hilda lives an idealistic and well-off life in the traditional sense. Her responsible husband Rupert, a high-ranking civil servant, is working on a book concerning moral issues. Unlike her sister Morgan, Hilda doesn't receive a college education as an intellectual, which she regrets a lot. So she considers herself not one of "the trained minds" (Murdoch, 2001, p.16) and not "an academic type" (Murdoch, 2001, p.17). She is "always busy serving others" (Murdoch, 2001, p.199). She performs good works and belongs to several charitable organizations. The first setting in the novel is the celebration of their $20^{\text {th }}$ wedding anniversary in the garden of their big house located in the rich area in London. Murdoch describes her as "a plumper 
angel" (Murdoch, 2001, p.1) and the couple as "a handsome pair" (Murdoch, 2001, p.1) for "they were altruistic, but treated themselves judiciously to luxuries" (Murdoch, 2001, p.1). But Morgan's unexpected intrusion to the house destroys the joyful and peaceful home atmosphere and her return opens the prelude to the unforeseen events in Hilda's life. Morgan's return impacts on Hilda's life more violently than anything that she expected and lays "her soul open to fears" (Murdoch, 2001, p.57) because she expects much from it, "almost a renewal of life" (Murdoch, 2001, P.265). And the following happenings prove her presentiment.

Murdoch seldom casts the image of the perfect mother in her novels, and Hilda is not exceptional. The only flaw in her life is that her only child Peter seems likely to drop out of Cambridge. Ironically, Rupert's moral philosophy is signally ineffective in relation to his son. For Hilda, Peter's dropout and rebellion is "such a cloud on the horizon" and she "can't help worrying the whole time with Peter in this awful mood" (Murdoch, 2001, p.17). Peter is lodging with Tallis, who his parents hoped would be a good influence, but whose virtue seems as useless as Rupert's philosophy. Hilda is not a confident and successful mother since "when the prospect of meeting Peter was close it was now always rather alarming" (Murdoch, 2001, p.57). And she admits to her son with tears that she is "just no good at being a parent" (Murdoch, 2001, p.60). Murdoch illustrates women's general dilemma as being a mother through Hilda's situation:

This meant that she was a unique and precious being to him, but it also meant that it was her special privilege to put up humbly and uncomplainingly with any degree of casualness and neglect. Peter knew that it was a metaphysical impossibility that her love for him should diminish by one iota whatever he might or might not do, and this precisely enabled him to dismiss her altogether from his mind. (Murdoch, 2001, p.266)

Hilda is so strong-willed and self-controlled as not to be "addicted to feeling sorry for herself" (Murdoch, 2001, p.266) and then to concentrate herself upon other matters. In other sense, Hilda is not a dutiful mother since she takes no effective measures to help her son except some trivial and empty talks with him in tears.

Hilda's contented world is severely shaken by the discovery of the fact that Peter falls in love with his aunt Morgan and completely collapsed by the news of the likely involvement between her husband Rupert and Morgan. When Julius hints the love affair between Morgan and Peter to Hilda, she feels "completely puzzled" (Murdoch, 2001, p.270) and "then frightened, as if her life was suddenly menaced" (Murdoch, 2001, p.270). Still being greatly shocked and unaware of Julius' scheme, Hilda is broken down by Julius' lie that Rupert and Morgan are involved with each other. "On reflection it seemed absurd and everything that she feared so shadowy" (Murdoch, 2001, p.293). She consoles herself by imaging that perhaps "Morgan was in some secret trouble and Rupert was helping her? Perhaps she was in some trouble which she would feel ashamed to confess to Hilda? This supposition had a ring of sense about it. ... Morgan was in trouble, Rupert was helping" (Murdoch, 2001, p.293). However, Julius tempts her to believe its facticity and become suspicious of Rupert's unchanged love to her:

Julius's company had been a stimulus. Now that he was gone she felt utterly dejected and rather frightened. ... Hilda thought, I must do something to stop myself from getting panic-stricken. ... She could feel her eyes staring with fright. She thought, I must find something to hold onto, something to peg me down into the real world, something to make me believe in the reality of the past. (Murdoch, 2001, p.323)

Dejected and rather frightened, Hilda is awakened to reexamine her self-awareness as a wife and even as a human being in the past and at present. She suspects that Rupert regrets having married her for "she was not clever, she was not an intellectual. She had been a very dull wife for such a brilliant man. Why should he love me, after all? Perhaps there had been gradual slow regrets" (Murdoch, 2001, pp.293-4).

While she questions Rupert's satisfaction with the marriage as well as hers, "Her own motives for self-deception were strong and for the first time visible to her" (Murdoch, 2001, p.316). Hilda begins to be aware of the fact that she only exists in the self-other relationships since people around her take it for granted "that Hilda had no personal life" because "happily married people don't" (Murdoch, 2001, p.389). Hilda is Rupert's wife and Morgan's sister and Peter's mother, and "into these eminently satisfying relationships the whole of that generous being was without residue absorbed" (Murdoch, 2001, p.389). So Morgan's two love affairs respectively with Peter and Rupert deprive Hilda of all the social roles and destroy the meaning of her existence. As for her husband, she has "a shudder intuit a whole dimension of otherness, Rupert's otherness" (Murdoch, 2001, p.324). She finds she knows nothing about all kinds of thought and needs and impulses Rupert has. And as far as Morgan is concerned, Hilda is "utterly impossible to exist with her" (Murdoch, 2001, p.378) and cannot accept her back into her life. Being destroyed by "that particular alliance" (Murdoch, 2001, p.378) and "by that special and absolute cruelty" (Murdoch, 2001, p.378), Hilda feels she has no future while others have. Her sense of being drives her to ask herself what will become of her now.

Hilda's life is completely destroyed by that particular betrayal which "had injected its venomous power into the whole of her past, changing all that was good into torrent specious appearance" (Murdoch, 2001, p.379). As an image of happy housewife, Hilda is cast as the most substantially good character in the novel: warm, witty, self-effacing, and shrewd. She keeps busy with volunteer charity and community work, and at least equals her husband in common sense and compassion. Besides, she puts into effect what her husband probably theorizes about in his treatise on love and virtue. However, the betrayal of her sister and husband leave Hilda totally lost in her life path regardless of these traditional virtues she owns. "Everything was different now right back to the start" (Murdoch, 2001, p.379). To find a way out, she chooses to flee to the cottage alone instead of clarifying the whole event with Rupert and Morgan, 
imagining that the cottage would be a refuge and the solitude there could provide a kind of freedom. "She had imagined herself sitting there and steadily thinking things out" (Murdoch, 2001, p.378). However, it turns out to be that "the loneliness and all sorts of physical fears...had reduced her to such a state of panicky misery that she was quite incapable of thinking at all" (Murdoch, 2001, p.378). When she realizes her lack of self-awareness as an individual and urges to think about herself as well as her future life, both the physical and mental sufferings hinder her from thinking at all. Even without finding her way out, she starts to regret for her absence without notice. "There'll have to be talk and it's unkind as well as cowardly to run away like this" (Murdoch, 2001, p.380). After Julius told her the truth of the matter, she feels the eagerness of talking to Rupert at once for that all was unchanged and then ask him to forgive her. The reflection on her reaction to the whole event makes her reproach herself for her instant judge on Rupert, little faith in her husband and her sister because "[A]11 those years of love and trust should have made her at least wait, at least keep quiet" (Murdoch, 2001, p.385). With the phone being broken down, Hilda sets out immediately for home regardless the heavy rain at night. The journey to her female self-awareness abruptly ends when Hilda starts on the way back home and back to her past life.

\section{CONCLUSION}

In A Fairly Honourable Defeat, Murdoch puts the problems that traditional women and modern women may encounter on the way to quest for the female self-awareness in comparison. Murdoch depicts two different female characters in this novel: one with traditional women's virtues and the other with modern women's advantages. So while exploring for their female self-awareness, they experience different problems. As the typical example of "the Angel in the House", Hilda is content with her life as a wife, mother and sister and has no sense of her individual self before her marriage crisis while Morgan struggles to find what she is and what she wants from the very beginning. Hilda is always other-regarding, so she considers the meaning of her existence for others but not as an independent individual woman. The farce conducted by Julius makes her aware of the lack of self-awareness and determined to think seriously about herself and her future. But her mind draws a blank and leads her nowhere near the full awareness of herself. So she chooses to be what she was without any hesitation with the end ripped out. Though she withdraws her step on the way to quest for her female self-awareness, Hilda has been conscious of her own situation as a woman after these twists and turns in her life. Meanwhile, as an intellectual woman with the advantages brought by the Women's Movement, Morgan is self-regarding and has a totally different trajectory of life. Her education and academic career do not ensure her an easier way if not rougher than her elder sister, which fails to guarantee her a happier life than the traditional peers.

Murdoch focuses on the characterization of the siblings Hilda and Morgan respectively as a typical example of traditional women and modern educated women. Compared with Morgan's emotional perplexity, economic hardship, and male contempt, Hilda's affluent life, happy marriage and her popularity among the male indicate Murdoch's reluctant admission that women still live in the androcentric world where the women's self-improvement are not widely welcome.

\section{ACKNOWLEDGEMENT}

Supported by“the Fundamental Research Funds for the Central Universities”, Project No. DUT14RW212. XU Ming-ying, Ph.D., associate professor, School of Foreign Languages, DalianUniversity of Technology.

\section{REFERENCES}

[1] Beauvoir, Simone de. (1953). The Second Sex. H. M. Parshley (trans. \& ed.). London: Jonathan Cape.

[2] Butler, Judith. (1986). Sex and Gender in Simone de Beauvoir's Second Sex. Wenzel, H. V., (ed.). Yale French Studies: Simone de Beauvoir: Witness to a Century, New Haven: Yale University Press. 35-49.

[3] Dipple, Elizabeth. (1982). Iris Murdoch: Work for the Spirit. Chicago: University of Chicago Press.

[4] Dooley, Gillian. (2003). From a Tiny Corner in the House of Fiction: Conversations with Iris Murdoch. Columbia: University of South Carolina Press.

[5] Murdoch, Iris. (2001). A Fairly Honourable Defeat. New York: Penguin Books.

[6] Pugh, Martin. (2000). Women and the Women's Movement in Britain 1914-1999. $2^{\text {nd }}$ ed. Basingstoke: Macmillan.

Mingying Xu was born in Harbin, China in 1977. She received her PH.D. degree in English Language and Literature from Shanghai International Studies University, China in 2013.

She is currently an associate professor in the School of Foreign Languages, Dalian University of Technology, Dalian, China. Her research interests include British and American literature and literary criticism. 